\title{
The influence of the wave length of light on the movements of chloroplasts in Lemna trisulca L.
}

\section{ALICJA ZURZYCKA \\ wpł. 22.XII.50. \\ I. INTRODUCTION:}

The movements of chloroplasts in cells were first discovered by B ö h m (1856) and investigated by $\mathrm{F}$ a $\mathrm{m}$ i $\mathrm{n} \mathrm{t} \mathrm{z}$ i n (1867/8), $\mathrm{F} \mathrm{r} \mathrm{a} \mathrm{n} \mathrm{k}(1871,1872)$ and $\mathrm{S} \mathrm{t}$ a h $\mathrm{l}$ (1880) but the most thorough investigations were done by $\mathrm{S}$ e $\mathrm{n} \mathrm{n}$ (1904, 1908, 1909 a, 1917, 1919). In $1909 \mathrm{~S}$ e $\mathrm{n} \mathrm{n}$ published a synthesis of the results he and his predecessors obtained.

The movement of chloroplasts is a phenomenon common to all plants, though the manner in which this change of position takes place varies in different plants. For these reasons $\mathrm{S}$ e $\mathrm{n} \mathrm{n}$ in his work distinguishes several types according to which the phenomenon occurs.

The movement of chloroplasts in Lemna trisulca L. develops according to the type which appears in the spongy parenchyma of higher plants. According to the intensity of light $\mathrm{S}$ e $\mathrm{n} \mathrm{n}$ distinguishes three characteristic positions of chloroplasts in cells of Lemna trisulca:

i) D i a s t r o p h e - the arrangement of chloroplasts in dispersed light

ii) A postrophe - the arrangement of chloroplasts in darkness

iii) $\mathrm{P}$ a r a s troph e - the arrengement of chloroplasts in very strong light. In nature this occurs under direct sunlight.

In the author's opinion there is no essential difference between the diastrophe in Lemna trisulca and the epistrophe which appears 
in the leaves of Funaria hygrometrica. For this reason in this paper the term e p i s t r o p h e was used to denote the arrangement of chloroplasts in diffused light.

The main difference between the arrangement of chloroplasts in the apostrophe and the parastrophe is that in the first case they place themselves against all the internal cell walls, and in the latter only against the walls perpendicular to the surface of the leaf. In diffused light the chloroplasts place themselves only against those walls which are perpendicular to the beam of light.

In the papers mentioned previously the influence of different ranges of the spectrum and of varied intensities of light on the arrangement of chloroplasts is dealt only descriptively and $\mathrm{V}$ o e r$\mathrm{k} \mathrm{e} \mathrm{l}$ (1934) is the first to give quantitative data on the influence of the colour and intensity of light on the transposition of chloroplasts in the cells of Funaria hygrometrica. He found that the movements of chloroplasts are dependent on the blue colour of light, and that red light does not produce any reaction.

In $\mathrm{V}$ o e $\mathrm{r} \mathrm{k}$ e l's experiments the starting position was usually the apostrophe, and data concerning the epistrophe were only accidental. However it appears that in the light of the latest investigations on the submicroscopic structure of the chloroplasts ( $\mathrm{H} \mathrm{u}$ b e r t 1935, F r e y W y s s l i n g 1937 and 1948), it is doubtful whether the reactions to a stimulus of light in the two positions are equivalent. For this reason it was thought worth investigating the reactions to the colour and intensity of light of chloroplasts so placed that their optical axis ( $\mathrm{R} \mathrm{a} \mathrm{b} \mathrm{i} \mathrm{n} \mathrm{o} \mathrm{w} \mathrm{i} \mathrm{t} \mathrm{s} \mathrm{c} \mathrm{h} \mathrm{1945)}$ was a parallel (epistrophe), b) perpendicular (apostrophe) to the rays of light.

The problems under investigation were:

1. The dependence of the movements of chloroplasts on the intensity and colour of light.

2. The change in position of chloroplasts in time.

3. The effect of light of different wave lengths and of constant intensity.

II. $\mathrm{M}$ e $\mathrm{t} \mathrm{h}$ o d $\mathrm{s}$.

For the experiments the plant Lemna trisulca (S t a h 1 1880) was used. This plant was found easier to adjust in the beam of rays without damaging its fronds than the Funaria hygrometrica used by $\mathrm{V}$ o e $\mathrm{rkel}$ in his experiments. The observations were done only on well developed edges of leaves with a single layer of cells. 
Epistrophe was induced by illuminating the leaf with an Osram $60 \mathrm{~W}, 220 \mathrm{~V}$ electric lamp from a distance of $30 \mathrm{cms}$ (V o e r k e l 1934). To induce apostrophe the plant was kept in darkness for 24 hours. This position was very difficult to obtain because in Lemna trisulca the apostrophe appears in its classical form only very occasionally, and as the frond grows older, the chloroplasts acquire a tendency to displace themselves evenly against all cell walls (S e n n 1908, L i n s b a e r and A b r a m o w i c z 1909).

To illuminate the plants with light of different wave lengths an apparatus consisting of an electric lamp, filters and a dark chamber in which the leaves were kept was assembled /fig. 1/.

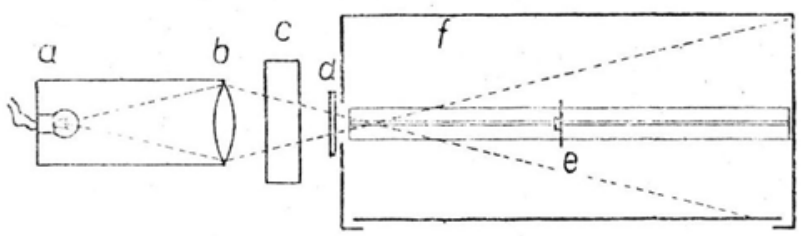

Fig. 1. Diagram of apparatus for illuminating cells. $\mathrm{a}-$ lamp, $\mathrm{b}-$ condensor of lamn, c - filter for absorbing ultra-red rays, d - colour filter, e - dark chamber, f - object, 1 - image of the source of light.

The source of $\mathrm{light}$. In the first and second stages of the investigation a low voltage Osram $35 \mathrm{~W} 12 \mathrm{~V}$ lamp was used. In the last stage the light came from a $250 \mathrm{~W} 125 \mathrm{~V}$ Csram projection lamp joined to the circuit by means of a $110 \mathrm{~V}$ transformer.

F i 1 t e r s. Light of different wave lengths was obtained by transmission throught filters the range of transparency of which lay within limits of:

blue filter, $425-510 \mathrm{~m}_{\mu}$; yellow filter: 480 - the limit of red light green filter, 445 - 632 mp; red. filter, 592 - the limit of red light When illuminating with light of varying wave length and constant intensity it was found necessary to narrow the limits of transmission. As a monochromator could not be used, Fuess'/gelationous/ monochromatic filters were employed, and their ranges of tranmission were:

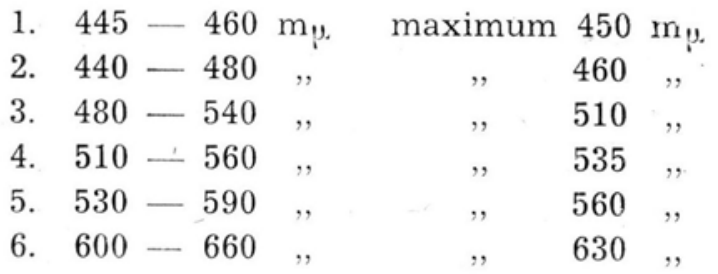


To absorb ultra-red rays, when experimenting with yellow, blue and green filters, a $2 \mathrm{cms}$ layer of a 7,5\% solution of copper sulfate was interposed: for the red filter a $3 \%$ solution of copper sulphate in a layer of the same depth was used (B a c h m a n n, 1929). In the 3 rd stage of investigation the $3 \%$ solution of copper sulphate was used in all experiments.

Measurements of the intensity of light. As the necessary apparatus for measuring the intensity of light was not available, the intensity was determined relatively. For this purpose in the preliminary experiments an application of the square distance law was made. The intensity was assumed to be 100 at the point where the rays intersected, after leaving the condensor of the lamp (see fig. 1).

Subsequently the light of the same intensity was determined by means of a thermopile and a Lange's „Multiflex“ type MGO galvanometer at the limit of $1 \mathrm{x}$. (sensivity 3,89.10-8 amp., internal resistance 12,59 ohms). The intensity was measured before and after the experiment and the readings varried by apprcximately $10 \%$.

$\mathrm{T}$ e m p e r a t u r e. Throughout the experiments the temperature was maintained between 18 and $21^{\circ} \mathrm{C}$.

III. $\mathrm{R}$ e s u $\mathrm{lt} \mathrm{s}$.

1. The dependence of the movements of chloroplasts on the intensity ard colour of $\mathrm{l}$ ig h t.

In this stage of the investigation the experiments were connected with $\mathrm{V}$ o e $\mathrm{r} \mathrm{k}$ e l's researches, and were concerned with obtaining data on the displacement of chloroplasts from the epistophe to parastrophe. Moreover it was examined whether the reaction to the colour and intensity of light in the apostrophe - parastrophe displacement was indentical in both Lemna trisulca and Funaria hygrometrica.

For the experiments the leaves were placed in a ring for tissue culture, and care was taken for the leaf to be perpendicular to the direction of light. The time was the same as in Voerkel's experiments, i.e. 3 hours. The percentage of the reaction was calculated, by counting the changes in the initial position of chloroplasts in 25 leaf cells. 
T A B L E 1 a.

Blue filler. Time of illumination: 3 hours

\begin{tabular}{c|c|c|c}
\hline \multirow{2}{*}{ No. } & $\begin{array}{c}\text { Relative intensisty } \\
\text { of light }\end{array}$ & $\begin{array}{c}\text { of } \\
\text { apostrophe } \\
\text { epistrophe }\end{array}$ & $\begin{array}{c}\text { opistrophe }- \\
\text { parostrophe }\end{array}$ \\
\hline 1 & 100 & 100,0 & 76,9 \\
2 & 25 & 100,0 & 76,9 \\
3 & 6,7 & 100,0 & 76,8 \\
4 & 2,8 & 100,0 & 63,8 \\
5 & 1,6 & 91,0 & 27,9 \\
6 & 1,0 & 100,0 & 14,6 \\
7 & 0,69 & 91,9 & 4,6 \\
8 & 0,64 & 70,9 & 0,0 \\
9 & 0,51 & 74,5 & 6,3 \\
10 & 0,41 & 21,26 & 4,5 \\
11 & 0,077 & 12,7 & 0,0 \\
& & &
\end{tabular}

T A B L E I b.

Green filter. Time of illumination: 3 hours

\begin{tabular}{c|c|c|c}
\hline \multirow{2}{*}{ No. } & $\begin{array}{c}\text { Relative intensity } \\
\text { of light }\end{array}$ & $\begin{array}{c}\text { \% of reaction } \\
\text { apostrophe } \\
\text { epistrophe }\end{array}$ & $\begin{array}{c}\text { epistrophe }- \\
\text { parastrophe }\end{array}$ \\
\hline 1 & 100 & 100,0 & 31,8 \\
2 & 25 & 100,0 & 22,6 \\
3 & 6,7 & 100,0 & 20,9 \\
4 & 2,8 & 65,4 & 6,4 \\
5 & 1,6 & 61,3 & 0,0 \\
6 & 1,0 & 50,0 & 0,0 \\
7 & 0,69 & 38,2 & 0,0 \\
8 & 0,64 & 1,6 & 0,0 \\
9 & 0,51 & 5,0 & 5,6 \\
10 & 0,41 & 0,0 & 0,0 \\
\end{tabular}


A. Zurzycka

T A B L E I c.

Yellow filter. Time of illumination: 3 hours

\begin{tabular}{c|c|c|c}
\hline \multirow{2}{*}{ No. } & $\begin{array}{c}\text { Relative intensity } \\
\text { of light }\end{array}$ & $\begin{array}{c}\mid c \\
\text { apostrophe } \\
\text { epistruphe }\end{array}$ & $\begin{array}{c}\text { op reaction } \\
\text { parastrophe }\end{array}$ \\
\hline 1 & 100 & 49,3 & 14,2 \\
2 & 25 & 30,4 & 4,2 \\
3 & 6,7 & 19,1 & 8,9 \\
4 & 2,8 & 6,7 & 0,0 \\
5 & 1,6 & 9,3 & 12,4 \\
6 & 1,0 & 1,9 & 6,9 \\
7 & 0,16 & 11,3 & 9,3 \\
8 & 0,54 & 10,2 & 2,2 \\
9 & 0,51 & 10,6 & 0,0 \\
10 & 0,41 & 10,7 & 6,3 \\
& & &
\end{tabular}

T A B L E I d.

Red filter. Time of illumination: 3 hours

\begin{tabular}{r|c|c|c}
\hline \multirow{2}{*}{ No. } & $\begin{array}{c}\text { Relative intensity } \\
\text { of light }\end{array}$ & $\begin{array}{c}\text { \%ostrophe }- \\
\text { epistrophe }\end{array}$ & $\begin{array}{c}\text { epistrophe - } \\
\text { parastrophe }\end{array}$ \\
\hline 1 & 100 & 3,3 & 98,1 \\
2 & 25 & 4,2 & 99,0 \\
3 & 6,7 & 5,7 & 94,8 \\
4 & 2,8 & 6,2 & 78,0 \\
5 & 1,6 & 4,6 & 67,2 \\
6 & 1,0 & 0,0 & 65,9 \\
7 & 0,69 & 3,9 & 49,8 \\
8 & 064 & 7,3 & - \\
9 & 0,51 & 0,0 & - \\
10 & 0,41 & 6,0 & 17,9
\end{tabular}


The results obtained are assembled in Tables $\mathrm{I} a-\mathrm{d}$ and in Figs. $2-5$. On the graphs ordinates represent the percentage of

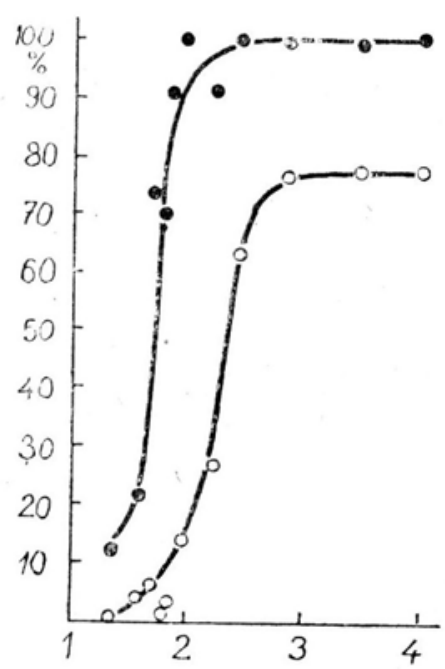

Fig. 2. Movement of chloroplasts in cells of Lemna trisulca under the influence of blue light. o-o epistrophe-parastrophe reaction, apostrophe - epistrophe reaction.

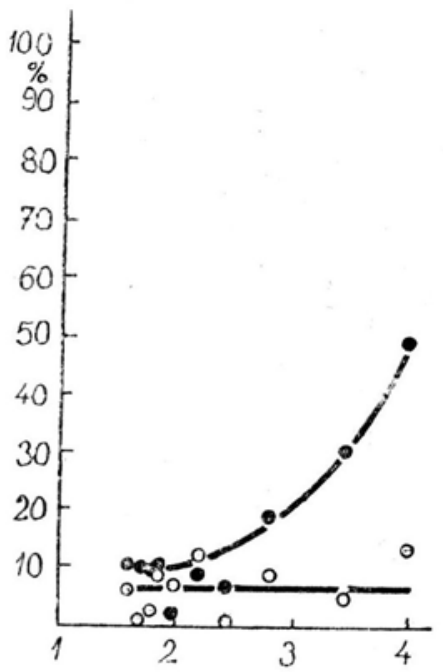

Fig. 4. Movement of chloroplasts in cells of Lemna trisulca under the influence of yellow light. Details as in. Fig. 2.

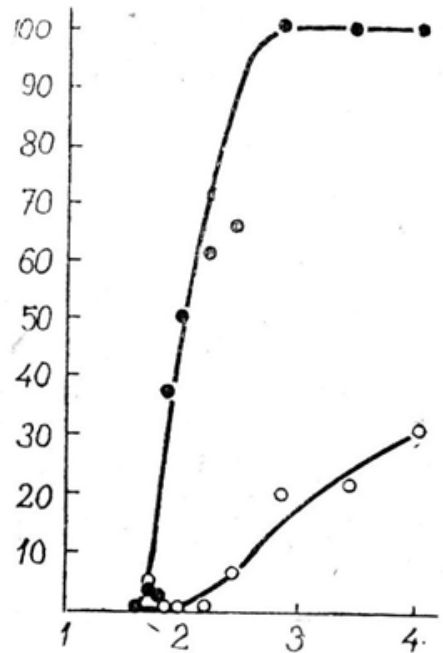

Fig. 3. Movement of chloroplasts in cells of Lemna trisulca under the influence of green light. Details as in Fig. 2.

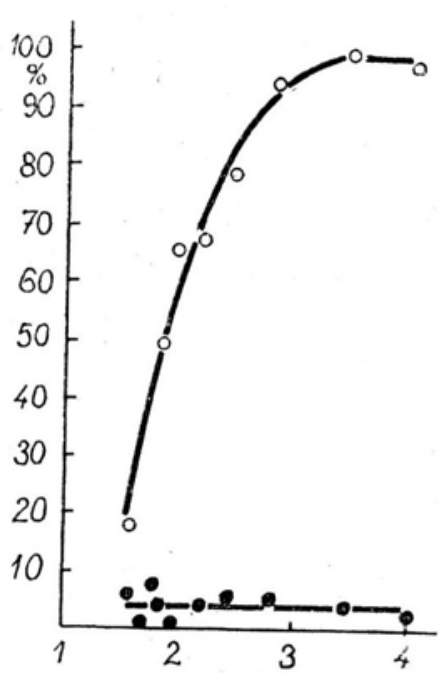

Fig. 5. Movement of chloroplasts in cells of Lemna trisulca under the influence of red light. Details as in Fig. 2. 
the reaction, and the abscissa the logarythms of the relative intensities of light +2 ; the graphs ilustrate the effect of given wave lengths of light, when the initial possitions were the apostrophe and the epistrophe. The tables and graphs demonstrate that the reaction to the different spectral ranges explicite depends on the position of the chloroplasts towards the light which falls on them. The differences in the reactions are most marked in red light. No change of position of chloroplasts was obtained if the initial position was the apostrophe, which is in agreement with $\mathrm{V}$ o e $\mathrm{r} \mathrm{k}$ e ls results. On the other hand if the optical axis of chloroplasts was parallel to the rays of light - according to its intensity - complete or partial parastrophe appeared.

Blue light causes a reaction in both initial positions, though in the case of epistrophe it has less effect than when the apostrophe is the initial arrangement.

The results obtained with green light are similar to those caused by blue light, though the difference in the percentage of reaction in the two initial possitions was much higher in the case of green light. In yellow light the reaction is very feeble, which is not necessarily due to the inability of the pigments in chloroplasts to absorb yellow light but may be caused also by the very small selectiveness of the filter $/ 480 \mathrm{~m} \mu$ - limit of $\mathrm{red} /$.

The influence of different intensities of light of one colour was very similar to what $\mathrm{V}$ o e $\mathrm{rk}$ e 1 described: for each intensity there is a corresponding percentage of the reaction.

According to some authors the effects of red light and of darkness are identical ( $\mathrm{F} \mathrm{r} \mathrm{a} \mathrm{n} \mathrm{k} \mathrm{1872,} \mathrm{S} t \mathrm{ta} \mathrm{h} \mathrm{l} 1880$, $\mathrm{S}$ e $n \mathrm{n}$ 1908). For this reason when investigating the effect of red light in the epistrophe to parastrophe reaction, a control experiment was run for three hours in darkness /epistrophe to apostrophe/. The results obtained are given in Table II.

T A B L E II

Time of experiment: 3 hours. Starting position: ep:strophe

$\%$ of parastrophe in red light of relative intensity 100

$\%$ of apostrophe in darkness

\begin{tabular}{r|r}
98.07 & 40.00 \\
98.57 & 41.81 \\
93.41 & 31.15 \\
95.70 & 41.84 \\
$\mathrm{M}=96.44$ & $\mathrm{M}=38.70$
\end{tabular}


It appears from Table II that the effect of red light was 2,5 times greater than the effect of darkness.

2. The change in position of chloroplasts in time.

The strong effect which red light has on the change in the position of chloroplasts from the epistophe to parastrophe, and on the other hand the lack of any reaction when the initial position is apostrophe (Fig. 5), can suggest that in the latter case a chain of reactions could take place during the three hours of the experiment i.e. apostrophe - epistrophe - parastrophe.

For this reason in this stage of the present investigations special attention was given to a detailed observation of the transposition of chloroplasts versus the time and to the wave langth of light of constant intensity. Similar problems were dealt with by $\mathrm{L}$ e w i s (1898) in his work on chloroplast movements in Mugeotia, and $\mathrm{V}$ o e rke 1 in Funaria hygrometrica. Both these authors however limited their researches to white light. To unable the observation of the reaction throughout the experiment it was found necessary to modify the apparatus used previously. This was done by placing a microscope horizontally in the beam of the rays of light. The magnification obtained (Eyepiece $10 \mathrm{x}$, objective $40 \mathrm{x}$ ) made it easy to observe 25 cells in the leaf of Lemna trisulca.

T A B L E III

Time of illumination: 3 hours

Relative intensity of light: 30

\begin{tabular}{|c|c|c|c|c|}
\hline \multirow{3}{*}{$\begin{array}{l}\text { Time in } \\
\text { minutes }\end{array}$} & \multicolumn{4}{|c|}{$\%$ of $\quad \mathrm{r}$ e a c t i o n } \\
\hline & \multicolumn{2}{|c|}{ epistrophe - parastrophe } & \multicolumn{2}{|c|}{ apostrophe - epistrophe } \\
\hline & blue light & red light & blue light & red light \\
\hline 0 & 100,0 & 100,0 & 23,5 & 5,2 \\
\hline 15 & 71,3 & 64,6 & 38,5 & - \\
\hline 30 & 45,5 & 48,4 & 53,1 & 8,9 \\
\hline 45 & 27,0 & 37,5 & 79,3 & - \\
\hline 60 & 21,3 & 29,2 & 97,2 & 7,2 \\
\hline 75 & 17,2 & 一 & 100,0 & - \\
\hline 90 & 14,8 & 24,5 & 100,0 & 7,5 \\
\hline 105 & 11,1 & & 100,0 & - \\
\hline 120 & 17,2 & 23,9 & 100,0 & 8,0 \\
\hline 135 & 23,3 & - & - & - \\
\hline 150 & 20,5 & 16,1 & 100,0 & 8,5 , \\
\hline 165 & 25,0 & - & - & - \\
\hline 180 & 24,7 & 14,6 & 100,0 & 4,2 \\
\hline
\end{tabular}


Only the changes taking place in blue and red light were observed and the filters used were the same as in the previous experiments. The reasons for discontinuing experiments in green and yellow light were: 1) the insufficient selectiveness of filters and 2) that the reaction which takes place in these wave lengths is intermediary between the reactions taking place in red and blue light. The relative intensity of light was fixed at 30 and measured by means of the thermopile. To prevent any changes in the intensity of light the condensor was removed from the microscope. In a control experiment the change of position of chloroplasts in darkness was observed. Each reaction was repeated four times.

T A B L E IV

Time of darkness: 3 hours

\begin{tabular}{r|r}
\hline Time in minutes & $\begin{array}{c}\% \text { of reaction } \\
\text { epistrophe }- \text { apostrophe }\end{array}$ \\
\hline 0 & 100,0 \\
10 & 100,0 \\
30 & 100,0 \\
40 & 100,0 \\
50 & 93,5 \\
60 & 75,5 \\
70 & 62,9 \\
90 & 48,1 \\
110 & 47,2 \\
130 & 33,8 \\
150 & 39,4 \\
170 & 34,7 \\
& 53,7 \\
\hline
\end{tabular}

The results obtained for the apostrophe - epistophe and epistophe - parastrophe reactions are given in Table III and Figs. 6 and 7 and for the reaction epistophe to apostrophe in Table IV and Fig. 8. These tables and graphs make it possible to interprete the results of the first part of the investigation more thoroughly and the conclusions reached are: 1) in red light the previously suggested chain of reactions does not take place (Fig. 7) 2) in the preceding experiments the parastrophe obtained in blue light was not complete (the 
parastrophe was $76,9 \%$ in the same intensity of light). It can be seen from Table III and Fig. 6 that this was due to a secundary displacement of chloroplasts from parastrophe to epistrophe caused by the excessively long time of illumination, 3) the reaction time in darkness at the experimental temperature of $18-21^{\circ} \mathrm{C}$ was in Table $\mathrm{V}$

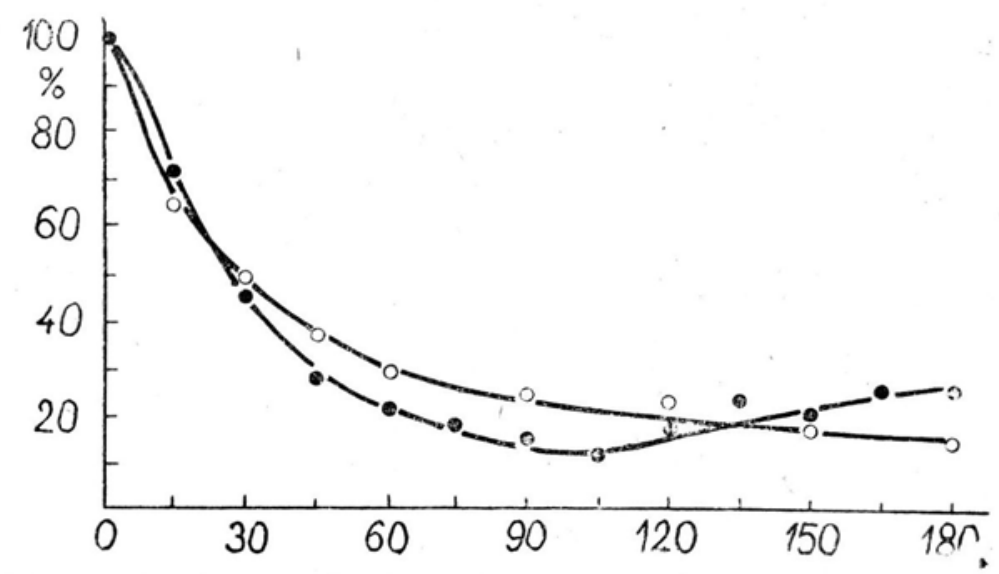

Fig. 6. The development in time of the epistrophe - parastrophe reaction. ${ }_{0}-{ }_{0}$ in red light, $\_$in blue light.

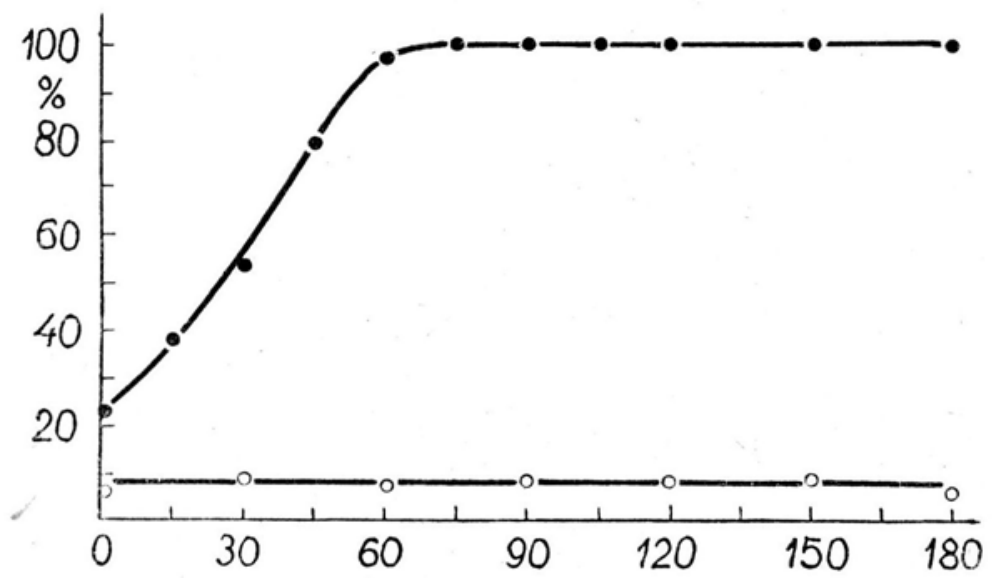

Fig. 7. The development in time of the apostrophe - epistrophe reaction. ${ }_{0}-{ }_{0}$ in red light, $\bullet-\bullet$ in blue light.

related to the time of the epistrophe to parastrophe reaction in red light. The calculating of the reaction time of chloroplasts in darkness was done according to the method chosen in an investigation on the influence of temperature on chloroplast movements $(\mathrm{Z} \mathrm{u} \mathrm{r} \mathrm{z} \mathrm{y} \mathrm{c} \mathrm{k} \mathrm{a}$ and $\mathrm{Z} \mathrm{urz} \mathrm{y} \mathrm{c} \mathrm{k} \mathrm{i} \mathrm{1950).}$ 
The time of chloroplast reaction calculated as the interval needed for $50_{0} f^{0}$ of chloroplast to move to a position opposite to the initial one

Type of reaction

Reaction time in minutes

epistrophe to parastrophe in red light epistrophe to apostrophe in darkness

$28,87 \pm 0,40$

$76,50 \pm 1,12$

3. The effect of light of different wave lengths and of constant intensity.

At this stage of the investigation the intention was to compare the effect of light of different wave lengths but of the same intensity per unit of time and surface, for wave lengths within ranges of 4000 to $7000 \AA$ and for the epistrophe - parastrophe and apostrophe - epistrophe processes. The aparatus used is ilustrated in Fig. 1. On the basis of the results obtained proviously the time of the expe-

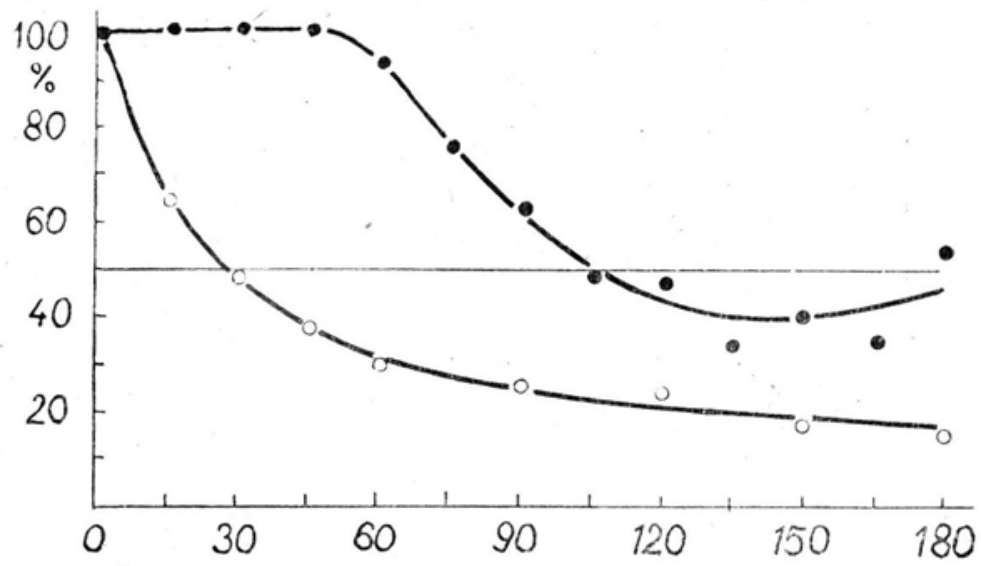

Fig. 8. The development in time of the epistrophe - parastrophe reaction. in red. light ${ }_{0}-0$ and epistrophe - apostrophe reaction in darkness

riments was reduced to 70 minutes. Every experiment was repeated four times for each range of wave lengths, and from the results obtained (i.e. from ractions in 100 cells) average values were calculated. These are given in Table VI and in Figs. 9 and 10. To simplify the graphs only the maxima of transparency of filters and not the range of transparency were marked on the abscissae (in Table VI the maxima are in brackets). The curve of the epistrophe - parast- 
T A B L E VI

Time of illumination $\mathrm{CuSo}_{4}$ filter $(3 \%, \mathrm{~d}-1 \mathrm{~cm})$ Relative intensity of light -80

\begin{tabular}{c|c|c}
\hline \multirow{2}{*}{$\begin{array}{c}\text { Wave lenght of light } \\
\text { in } \mu^{*}\end{array}$} & $\begin{array}{c}\text { R e a c t i o } \mathrm{n}: \\
\text { epostrophe }-\end{array}$ & $\begin{array}{c}\text { epistrophe } \\
\text { parastrophe }\end{array}$ \\
\hline $660-600(630)$ & $40,38 \pm 5,77$ & $73,18 \pm 1,47$ \\
$590-530(560)$ & $42,24 \pm 2,69$ & $33,19 \pm 1,83$ \\
$560-510(535)$ & $73,38 \pm 2,01$ & $21,02 \pm 2,54$ \\
$540-480(510)$ & $85,99 \pm 5,06$ & $19,08 \pm 2,76$ \\
$480-440(460)$ & $93,32 \pm 4,63$ & $57,62 \pm 2,48$ \\
$460-445(450)$ & $90,16 \pm 2,61$ & $68,01 \pm 2,13$
\end{tabular}

rophe process has two maxima: the first maximum is in red light $(73,18 \pm 1,47)$ and the second one in blue light $(68,10 \pm 2,13)$. The only maximum of the apostrophe - epistrophe reaction is in bluegreen light. The horizontal dotted line in Fig. 10 denotes the average number of chloroplasts which, inspite of being kept in darkness for 24 hours, did not move to the lateral walls. Because of this results in the apostrophe - epistrophe process are overestimated, and in

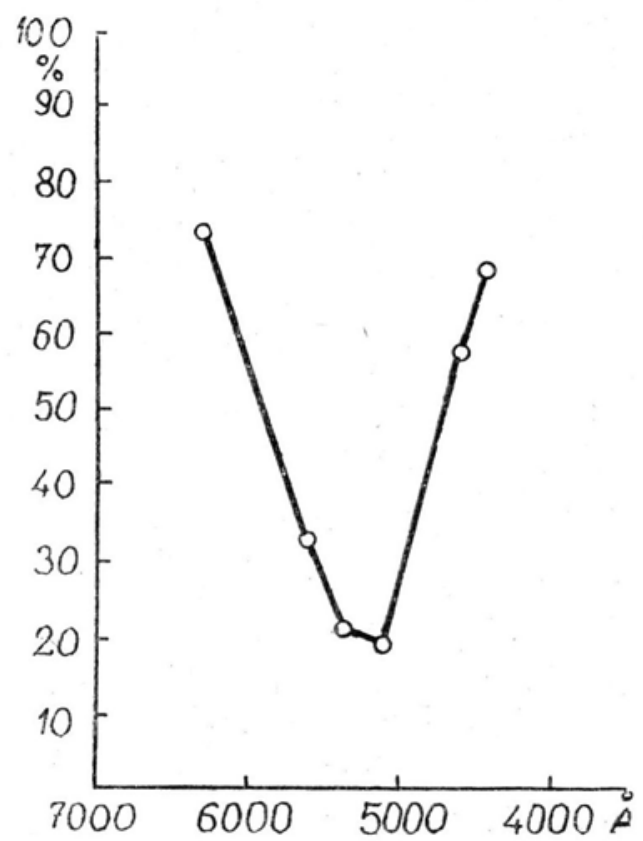

Fig. 9. The curve of the epistrophe - parastrophe reaction in relation to the wave lenght of light of a constant intensity. 
order to compare them with results of the epistrophe - parastrophe reaction they should be reduced by the initial number of chloroplasts in epistrophe i.e. by $30,01 \pm 1,04 \%$. The partial apostrophe is due to the age of the plants used in these experiments, which were done in late autumn, and not in spring and summer as was the case with those in the first two stages. S e' $n$ n (1908) states that as the cell grows older the chloroplasts lose their capability to react to darkness, and this is shown by the increasing number of chloroplasts remaining on the outer walls. For this reason it is perhaps possible to explain the comparatively considerable value of the average error through biological properties of reacting cells in the apostrophe epistrophe reaction (cf. Table VI). There are no difficulties in obtaining the parastrophe regardless of whether the cell is young or old.

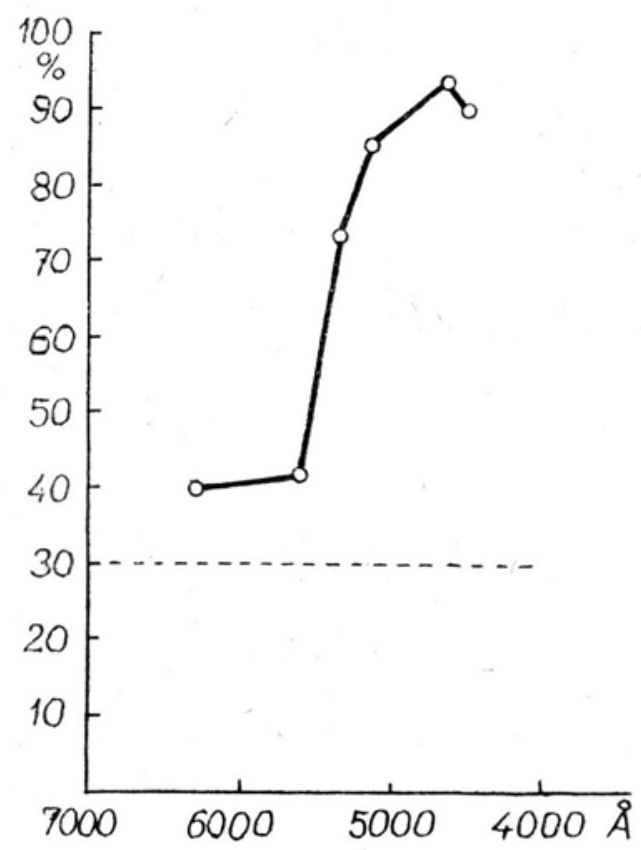

Fig. 10. The curve of the apostrophe - epistrophe reaction in relation to the wave lenght of light of a constant intensity.

IV. Discussion.

The results of researches on the influence of wave lenght on the movements of chloroplasts - initiated by B ö h $\mathrm{m}$ (1856) - can be divided into two groups. The opinions of those few students who maintain that red light has an influence on the displacement of chloroplasts would be in one group. 
Lin s ba er and A bra mow i c z (1909) investigated the influence of light filtred through water solutions of $\mathrm{K}_{2} \mathrm{Cr}_{2} \mathrm{O}_{7}$ and of $\left[\mathrm{Cu}\left(\mathrm{NH}_{3}\right)_{4}\right](\mathrm{OH})_{2}$, and state that both blue and red light cause the parastrophe in Lemna trisulca. In their opinion the processes apostrophe - epistrophe and epistrophe - parastrophe are quite separate phenomena. The first one would be a phototactic process and latter would be associated with the assimilation of carbon dioxide. As the work of the two authors was concerned with other problems, they did not support their opinion with systematic experiments, stressing however the necessity of verifying their sporadic observations.

The work of $\mathrm{Lins}$ b a e r and $\mathrm{A} \mathrm{bra} \mathrm{mow} \mathrm{i} \mathrm{z}$ was criticized by S e n n (1908), who very definitely states that only blue light causes parastrophe, while rays of red light induce apostrophe and their effect is much slower.

In some older works on the movement of protoplasm indirect references to the influence of wave langth of light on chloroplast movements can be found. The reason for this is that the rapidity of the transposition of chloroplasts was taken as the measure of the rapidity of movement of the protoplasm. According to $\mathrm{N} \mathrm{o} \mathrm{t} \mathrm{h-}$ $\mathrm{m}$ a $\mathrm{n} \mathrm{n}-\mathrm{Z} \mathrm{u} \mathrm{c} \mathrm{k} \mathrm{e} \mathrm{r} \mathrm{k} \mathrm{a} \mathrm{n} \mathrm{d} \mathrm{l} \mathrm{(1915)} \mathrm{the} \mathrm{protoplasmic} \mathrm{movements}$ (= chloroplasts) in celles of Elodea canadensis are most pronounced under the influence of red light and the slowest in violet light.

Also S c h w e i c k e r t (1928) found that the strongest photodinetic effect is caused by red rays of light and that this effect diminishes as the length of waves decreases; in blue light another maximum appears. According to his hypothesis the rays absorbed by the chlorophyll would have the strongest effect on the movement of the plasma ( = chloroplasts).

The opinions according to which only blue ligth has an effect on the change of position of chloroplasts form the other group.

$\mathrm{F} \mathrm{r} \mathrm{a} \mathrm{n} \mathrm{k} \mathrm{(1871} \mathrm{and} \mathrm{1872)} \mathrm{maintains} \mathrm{that} \mathrm{blue} \mathrm{light} \mathrm{affects}$ the movements of chloroplasts and that the effect of red light is similar - though weaker - to the effects of darkness. F a m i nt z i n (1867/8) found that on Mnium sp. yellow light acts in the way as darkness and that blue light causes a ,daylight" arrangement of chloroplasts. This was confirmed by $\mathrm{S} \mathrm{t}$ a h $\mathrm{l}$ (1880) and $\mathrm{S}$ e $\mathrm{n} n$ (1908) comparing the results of researches on the influence of light on the movement of chloroplasts comes to the conclusion that this displacement is dependent on blue light. According to him 
it is only Mugeotia which does not conform to this pattern, as in this plant the profile arragement (parastrophe) is brought about by blue light, and red light causes the daylight arrangemet (epistrophe).

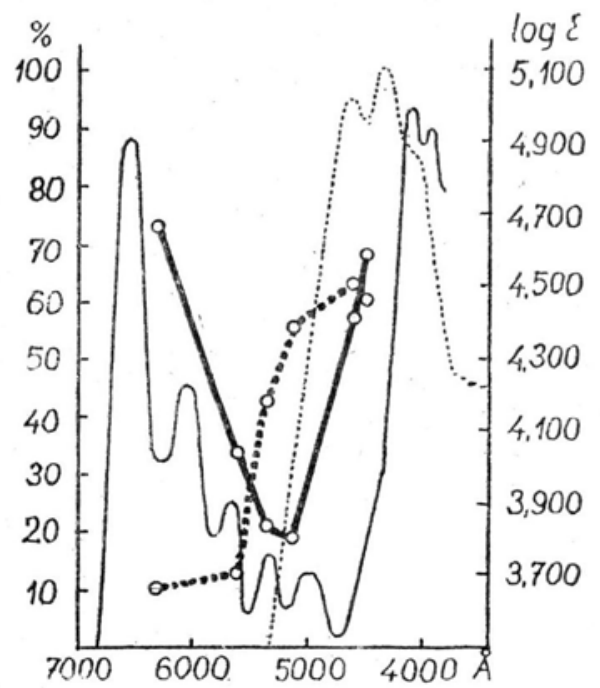

Fig. 11. The curves of the epistrophe - parastrophe ${ }_{0}^{-}$, and apostrophe epistrophe $0_{0}--{ }_{0}$, reactions within the range of visible radiation, and the curves of the absorption of light by leaf pigment in relation to wave length of visible radiation. - - - - - carotenes, chlorophyll a (H e i e r1 e 1935, quoted after F r e y - W y s s 1 i n g 1937).

In support of all these experiments no quantitative values were given. The first systematic experiments on the influence of wave lenght on the movements of chloroplasts were done by $\mathrm{V}$ o e $\mathrm{rk}$ e $\mathrm{l}$ (1934), who examined the influence on the displacement of chloroplasts of wave lengths ranging from ultra red to ultraviolet. However his most accurate experiments were concerned with the influence of visible radiation. He found that:

1. The reaction apostrophe - epistrophe was caused in Funaria hygrometrica by blue, yellow-blue and yellow-green light, in ratio of $273,3: 52,1: 1$ correspondingly, at a constant intensity of light. Even very intensive red light did not induce the epistrophe.

2. Within the range of visible radiation he could not induce the parastrophe even with light of the highest intensity. According to him this arrangement can be induced only by long ultraviolet rays. 
3. The influence of blue light on the reaction apostrophe - epistrophe is connected with the absorption of these rays by the carotenes.

The results obtained in the course of the present investigation on the process epistrophe - apostrophe in Lemna trisulca are in agreement with $\mathrm{V}$ o e $\mathrm{r}$ k e l's results obtained with Funaria hygrometrica. In Lemna trisulca visible short wave radiation has also a phototactic effect, while red light causes no reaction. (Figs. $2,5$ and 7$)$.

On the other hand the results obtained for the reaction epistrophe - parastrophe in Lemna trisulca are fundamentally different from the results in Funaria hygrometrica; the reason of this is that in the first plant the process is caused by visible radiation. The curve of the reaction (Fig. 11) has two maxima, one over $6000 \AA$ in red light and the other below $5000 \AA$ in blue light. There remains to explain why $\mathrm{V}$ o e r k e l did not obtain the parastrophe within the visible spectral range, though this is contradictory to the results obtained by his predecessors, and none of them deny the influence of blue light on this process. The explanation may lie in the experimental conditions used by $\mathrm{V}$ o e $\mathrm{r} \mathrm{k}$ e $\mathrm{l}$ to obtain the parastrophe. He employed a very powerful source of light (a $100 \mathrm{~W} 220 \mathrm{~V}$ lamp) illuminating the plants, from a distance of $15 \mathrm{cms}$ which in the case of blue light raised the temperature in the experiment to $29,5^{\circ} \mathrm{C}$. It has been found in the course of a recent research on the influence of temperature on chloroplast movements $(\mathrm{Z} \mathrm{u} \mathrm{r} \mathrm{z} \mathrm{y} \mathrm{c} \mathrm{k} \mathrm{a} \mathrm{and} \mathrm{Z} \mathrm{u}$ $\mathrm{r} \mathrm{z} \mathrm{y} \mathrm{c} \mathrm{k} \mathrm{i} \mathrm{1950)} \mathrm{that} \mathrm{at} \mathrm{a} \mathrm{temperature} \mathrm{of} 30^{\circ} \mathrm{C}$ and with a far weaker source of light (a $60 \mathrm{~W} 220 \mathrm{~V}$ lamp) the time needed for $50 \%$ of chloroplasts to attain the parastrophe is $4,95 \mathrm{mins}$. If also it is considered that blue light causes a secondary displacement of chloropiasts onto the outer cell walls (Table III and Fig. 7), it is plausible to suppose that in a 60 minute experiment the chloroplasts passed through a cycle of reactions - epistrophe - parastrophe - epistrophe - and returned to their starting positions. In red light when the epistrophe was the starting position - V o e r k e 1 obtained twice the parastrophe (V o e $\mathrm{r} \mathrm{k}$ e l, l.c. page 166). This was:

Experiment

No.
Time

Starting position

Epistrophe
40 mins.

85

,
Reaction in $\%$ of epistrophe

,

85

46,3

6,1 
$\mathrm{V}$ o e $\mathrm{r} \mathrm{k}$ e l quite probably overlooked these results, and this because his investigations were mainly concerned with the apostrophe - epistrophe process and the experiments on the epistrophe - parastrophe reaction were more or less accidental and done only to control the opposite one.

The experiments carried out, in the course of the present investigation, to compare the effect of red light and of darkness contradict S e n n's (1908) hypothesis according to which these two factors are equivelent. The reaction epistrophe - apostrophe is determined - in a very specific manner - by the biological properties of the cell, it is so because:

1. The reaction to the cutting off of the light is not immediate, but is preceded by a preparatory period (Fig 8), the duration of which depends among other factors on the temperature of the experiment. This preparatory period considerably prolongs the time of the reaction $=76,5$ mins. in the experimental temperature.

2. The percentage of chloroplasts which react depends on the age of the cell (see $\mathrm{S}$ e $\cap \mathrm{n}$ 1908).

On the other hand in red light the epistrophe - parastrophe process:

1. starts off immediately stimulation begins, and because of this the time of the reaction is much shorter $=28,88$ mins.

2. is depended on the intensity of light (Fig. 5 and Table Id)

3 . is not depended on the age of the cell (see the results obtained on spring and autumn plants, Figs. 5 and 11 correspondingly).

The assumption made previously that the type of the chloroplast reaction depends on the orientation of the chloroplasts to the beam of light is corroborated by the curve representing the epistrophe - parastrophe reaction and the curve representing the apostrophe - epistrophe reaction in Fig. 11.

The curve plotted for the apostrophe - epistrophe reaction which takes place in light filtered through monochromatic filters, is similar to the curve representing the absorption of light by the carotenes and xanthophylls (Fig. 11). It seems therefore obvious that this process is correlated with the absorption of light by the yellow-orange pigments which enter into the composition of the colouring-matter of chloroplasts. 
The phototaxis of chloroplasts would therefore be a specific case of a principle common to all plants which covrelates a positive phototropic reaction with the presence in the reacting organism of yellow-orange pigments or more exactly of beta-carotene (B ü nn i n g 1939).

The comparison of the curve of the epistrophe - parastrophe reaction (Fig. 11) with the curve of the absorption of light by leaf pigments (Fig. 11 H e i e r l e 1935 quoted after F r e y - W y ss l i n g 1937) suggests that it is the absorption of light by chlorophyll which causes the apostrophe - epistrophe process and that in relation to the apostrophe - epistrophe reaction this is a negative phototactic process.

The dissimilarity of reactions to light of different wave lengths in the two initial possitions seems to indicate that in the epistrophe - parastrophe process the only acting absorbent is chlorophyll, and on the other hand in the apostrophe - epistrophe process the only absorbent are the carotenes. The direction of the maximal absorption by chlorophyll must be therefore perpendicular to the direction of maximal absorption by carotenes. In the light of the researches on the submicroscopic structure of chloroplasts $(\mathrm{H} \mathrm{u}$ b e r t 1935, F r e y - W y s s l i n g 1937, 1948) this can be explained by the arrangement of pigments inside the chloroplasts.

\section{S U M M A R Y}

1. The influence of the wave length and intensity of light on the movements of chloroplasts in Lemna trisculca L. was investigated and a dependence of these relations on the arrangement of chloroplasts was found.

2. Curves for the apostrophe - epistrophe and epistrophe parastrophe reactions were plotted, and it was found that the first one is caused exclusively by light absorption of carotenes, and the iatter one by light absorption of chlorophyll only, and that the directions of maximal absorptions of the two pigments are perpendicular to each other. This proves the existence of a submicroscopic structure of chloroplasts.

3 . The development of the apostrophe-epistrophe, epistropheparastrophe reactions was determined and the dissimilarity in the effects of red light and of darkness was ascertained. 
A c k n o w le d g m e n t s.

The author wishes to express her most sincere gratitude for rheir most valuable suggestions and criticism to Professsor Dr F. G ó r s k i Director of the Laboratory of Plant Physiology of the Jagiellonian University of Kraków, whose kind interest and guidance encouraged her in her work and to Professor Dr H. N i e w o d n ic z a n s k i, Director of the Physical Institute of the Jagiellonian University of Kraków, in whose laboratory the experiments partially were done. The author is also most grateful to Miss Mgr D. K u n i$\$ \mathrm{z}$ ó w n a, assistant of the II Physical Laboratory of the JagielIonian University of Kraków for the help in preparing the apparatus recessary in this work.

LABORATORY OF PLANT PHYSIOLOGY OF THE JAGIELLONIAN UNIVERSITY.

\section{LITERATURE CITED.}

1. B a c h m a $\mathrm{n} \mathrm{n,} \mathrm{Fr.} \mathrm{1929.} \mathrm{Uber} \mathrm{die} \mathrm{Verwendung} \mathrm{von} \mathrm{Farbfiltern} \mathrm{für}$ pflanzenphysiologische Forschungen. Planta, 8, 487-521.

2. B ö h m, J. A. 1856. Beiträge zur näheren Kenntnis des Chlorophylls. Sitzgsber. kais. Akad. Wiss. Wien, Math.-naturwiss. Kl. 22, $479-512$.

3. B ü n n i n g. E. 1938 Phototropismus und Carotiroide. III Weitere Untersuchungen an Pilzen und höheren Pflanzen. Planta, 27, 583-609.

4. C a s t l e, E. S. 1935. Photic excitation and phototropism in single plant cells. Cold Spring Harbor Symposia on Quant. Biology.III, 230-277.

5. F a m i n t z i n. A. 1867/8. Die Wirkung des Lichtes und der $\backslash$ Dunkelheit auf die Vertetilung der Chlorophyllkörner in der Blättern von Mnium sp. Jb. wiss. Bot. 6, 45-49.

6. F a $\mathrm{m}$ i $\mathrm{n}$ t $\mathrm{z}$ i $\mathrm{n}, \mathrm{A}$. 1857/8. Die Wirkung des Lichtes auf Algen und einige andere ihnen nähe verwandte Organismem. Jb. wiss. Bot. 6, 1-44.

7. F r a n k, B. 1871. Über lichtwärts sich bewegende Chlorophyllkörner. Bot. Ztg. 29, 209-2î5 and 225-232.

8. F r a n k, B. 1872. UUber die Veränderung der Lage der Chlorophyllkörner und der Protoplasma in der Zelle, und deren innere und äussere Ursachen. Jb. wiss. Bot. 8, 216-303.

9. F r e y - W y s s 1 i n g, A. 1937. Der Aufbau der Chlorophyllkörner. Protoplasma, 29, 279-303.

10. F r e y - W y s s l i,n g, A. 1948. Submicroscopic morphology of protoplasm and its derivates. New York - Amsterdam, 155-166.

11. $\mathrm{H}$ a b e r 1 a $\mathrm{n} \mathrm{d} \mathrm{t,} \mathrm{G.} \mathrm{1918.} \mathrm{Physiologische} \mathrm{Pflanzenanatomie.} \mathrm{Leipzig.}$ $252-256$.

12. H u b e r t, B. 1935. The physical state of chorophyll in the living plastid. Rec. trav. bot. neerl. 32, 323-390. 
13. L e w i s, F. J. 1898. The action of light on Mesocarpus. Annals of Botany, $12,418-421$.

14. L i n s b a e r, K. und A b r a m o w i c z, E. 1909. Untersuchungen über die Chloroplastenbewegungen. Sitzgsber. kais. Akad. wiss. Wien Ma h.-nat. Kl. I, 118, 418-421.

15. $\mathrm{N} \circ \mathrm{t} \mathrm{h} \mathrm{m}$ a $\mathrm{n} \mathrm{n}-\mathrm{Z}$ u c k e r k a n d 1, N. 1915. Über die Erregung der Protoplasmaströmung durch verschiedene Strahlenarten. Ber. dtsch. Bot. Ges. 33, 301-313.

16. R a b i n o w i t c h, E. I. 1945.. Photosynthesis. New York.

17. $\mathrm{S} \mathrm{c} \mathrm{h} \mathrm{w} \mathrm{e} \mathrm{i} \mathrm{c} \mathrm{k} \mathrm{e} \mathrm{r} \mathrm{t,} \mathrm{H.} \mathrm{1928.} \mathrm{Untersuchungen} \mathrm{über} \mathrm{Photodinese} \mathrm{bei}$ Vallisneria spiralis. Jb. wiss. Bot. $68,79-134$.

18. S e n n, G. 1904. Die Dunkellage der Chlorophyllkörner. Winterthur, $1-11$.

19. S e n n, G. Die Gestalts- und Lageveränderung der Pflanzenchromatophoren. Leipzig.

20. S e n n, G. 1909. Meine Stellung zu der Arbeit: Linsbauer K. und Abramowicz E. Untersuchungen über die Chloroplastenbewegungen. Zt. Bot. $1,592$.

21. Sen n, G. 1909. Weitere Untersuchungen über Gestalts- und Lageveränderung der Chromatophoren. I, II. Ber. dtsch. Bot. Ges. 27, 12-27.

22. Sen n, G. 1917. Weitere Untersuchungen über Gestalts- und Lageveränderung der Chromatophoren. III. Verh. Naturforsch. Ges. Basel. 28. II, $103-122$.

23. Senn, G. 1919. Weitere Untersuchungen über Gestalts- und Legeveränderung der Chromatophoren. IV, V. Zt. Bot. 2, 81-141.

24. S t a h 1, E. 1880. Ưber den Einfluss von Richtung und Stärke der Beleuchtung auf einige Bewegungserscheinungen im Pflanzenreiche, Bot. Ztg. $38 \mathrm{nr} 118$.

25. Voerkel, S. H. 1934. Untersuchungen über die Phototaxis der Chlorozplasten. Planta, 21, 156-205.

26. Zurzycka A. and $\mathrm{Zurzycki}$ J. 1950. The influence of temperature on the phototactic movements of chloroplasts. Acta Soc. Bot. Pol. 20, $665-680$. 